\title{
The ecological certification as the economic mechanism of environmental management in Russia
}

\author{
Elena Belyaeva, Veronika Panaseykina, and Violetta Gassiy* \\ Kuban State University, 350040, Krasnodar, Russian Federation
}

\begin{abstract}
In the paper the issues of environmental management are considered. The authors also research the economic mechanisms of the stimulation of green market development in Russia. The authors reveal an important feature of environmental certification connecting it with a healthy lifestyle, improving the quality of life, and proper nutrition. The interrelationships between environmental management, ecological certification, green market and sustainable development are considered in the paper. In the article the causes of the growing interest to new characteristics of agricultural products are also justified including coronavirus disease (COVID-19) and the growing demand for green, organic food that helps to rehabilitate the health. The relevance of the green market development is also approved. The authors link the sustainable development to environmental certification as a way to claim the purity of goods and services. The authors research the case of ecological certification in sustainable development on the legal bases and economic regulation. Different types of the environmental services are considered and evaluated. During analysis the main problems in the ecological certification in Russia are revealed. In Conclusions the authors propose the perspectives for further researches of the environment certification.
\end{abstract}

\section{Introduction}

In modern Russia, the problems of environmental development and environmental safety are important. In the article, the object of research is environmental certification as a mechanism for the transition to the principles of a green economy. The implementation of environmental and economic approaches to the development of territories, the implementation of investment projects, as well as the development of the market for green products and services also requires an assessment of their compliance with modern environmental requirements. Environmental certification plays a special role in ensuring the country's food security. An important feature of the sustainable development of agriculture at present is its orientation towards a healthy lifestyle and its maintaining, improving the quality of life, and proper nutrition. The growing interest to such characteristics of

*Corresponding author: vgassiy@mail.ru 
agricultural products is due to the coronavirus disease (COVID-19) and the growing demand for green, organic food that helps to rehabilitate the organism. Therefore, the development of a green market for agricultural products is relevant. This issue is also linked to environmental certification as a way to claim the purity of agricultural products.

The certification due to ecological requirements occupies a special place in the market of environmental service. It is not only one of its segments, but also aneffective link that allows to combine management, ecological insurance, audit and consulting into a single system. Ecological certification is a market instrument for management of natural resources to the modern international standards.

Currently, ecological certification in our country is at the beginning of its development process. Although by joint efforts of the government the pla $\mathrm{n}$ of actions to prevent harm to the environment and directly to the health of citizens has been realized. It seems that the optimal result of eco-certification can be achieved not only through the forced termination of production, e ffective control by the dedicated agencies, but also through the addition of guarantees in the legislation for the protection in case of violating consumer rights (for example, the prohibition to import goods that do not meet ecological requirements, the introduction of waste-free production). With the help of eco-certification we can solve tasks for ensuring rational use of natural resources, protection of environment and human health from harmful effects of goods and services. Thus, ecological certifica tion is an essential element of the environmental services' market.

\section{Materials and Methods}

Ecological certification stimulates the producers to develop and to implement such technological processes and goods that do not pollute the environment. They also guarantee the consumer that goods are safe for his/her health, life, and the environment [1].

There is no common position in the science regarding to the definition of the "ecological certification".

$\mathrm{X}$. Font interprets this term as a measure of nature protection and observance of the ecological right to a favorable environment, the object of which are finished goods, new equipment, materials and substances [2].

M.A.O. Torres, Z. Kallas and S.I.O. Herrera consider ecological certification as a management actions to ensure the quality of goods, works and services of an ecological type in order to create an economic and legal mechanism for the realization of citizens' rights to a favorable environment [3].

C. Griesche and A.J. Baeumner explains this concept as an option of certification of goods, works and services, i.e. a specific activity for assessment of conformity for finished goods or other certified object to the requirements of technical regulations, standards or terms of the contract, including environmental protection and ecological safety [4].

Certainly, environmental certification is an important stage in the formation of a new type of market - the market for environmentally friendly goods and services. Environmental certification is needed for several reasons:

- the need for further integration of the Russian economy into the world community, which makes high demands on responsible products, safe and environmentally friendly;

- protection of the domestic market and consumers from hazardous types of products, harmful technologies;

- prevention of environmental pollution during the extraction, production, processing and transportation of dangerous goods, compliance with environmental requirements;

- the development of innovations in Russia, the introduction of environmentally friendly technologies in production, the transition to new types of processing;

- protection of public health, environmental education and promotion of a healthy lifestyle. 
Therefore, in this article, we propose to use the following definition of environmental certification as an activity to confirm the compliance of a product or service with the norms of rational environmental management, environmental protection, human health and its genetic fund.

The work also pays significant attention to legal management methods, international law in the field of environmental economics. Particular attention is paid to the analysis and application of international methods and tools for managing the market for environmentally friendly goods and services. Also, the study will classify environmental certification by application. Thus, the system of methods used in the study can be represented as follows:

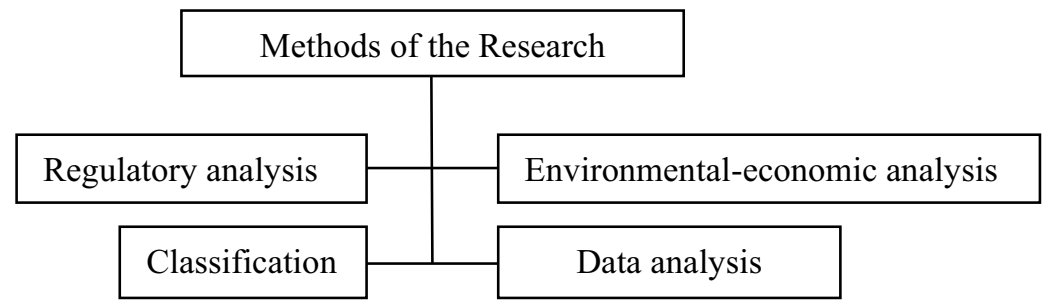

Fig. 1. Methods of the research

Ecological certification includes ecological certification of production and ecological certification of goods (Fig. 2). Ecological certification of goods is a conformity assessment procedure by which the organization depended of manufacturer (seller-dependent, contractor-dependent) and consumer (buyer) certifies in writing that the product meets the established requirements.

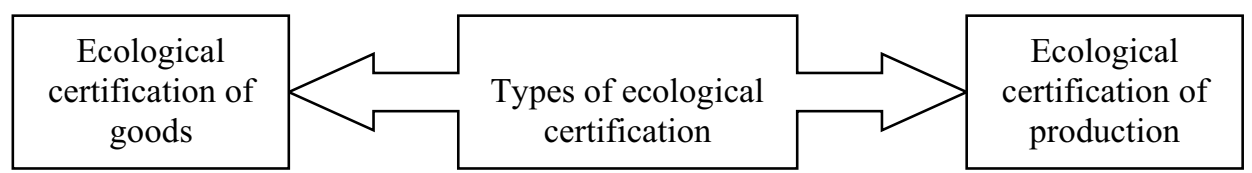

Fig. 2. Types of ecological certification

With the help of ecological certification, a number of important tasks are solved to ensure rational nature management, protection of environment and public health from the harmful effects of potentially environmentally hazardous goods or services [5]. Certification contributes to:

- prevention of appearance in the market and sale of environmentally hazardous goods and se rvices and, accordingly, prevention of harm to the natural habitat;

- introduction of ecologically friendly technological processes and equipment;

- production of ecologically friendly goods at all stages of their life cycle, improving their quality and competitiveness;

- creating conditions for the company-producer that meet the established ecological requirements;

- preventing the import of ecologically hazardous technologies, goods, wastes, services into the country;

- integration of the country's e conomy into the world ma rket and the fulfillment of internationa l obliga tions [6].

Ecological certifica tion of production is a broader concept, which includes not only goods certification as the main component of the entire process, but also the organizational and economic mechanism that allows, in accordance with technological requirements, to achieve the certification level of products. It can be said that it is a production process management system, including a product quality management system and an ecological management system [7]. 
The State Committee of the Russian Federation for Environmental Protection approved in December 1997 the main provisions of the Federal System on Obligatory Environmental Certification (FSOES). Since that time, ecological certification as a type of ecological service has received a new impetus for the de velopment.

At present an increasing number of organizations provide services for preparation and submission of documents for ecological certification of goods and services. In accordance to the Article 31 of the Federal Law dated on 10th Janua ry 2002 N7-FL "On environmental protection" ecological certification is carried out in order to ensure the environmentally friendly implementation of economic and othe $r$ activities in the Russian Federation.

Ecological certification in the Russian Federation is an activity to confirm the compliance of object under certification with environmental requirements established by the current legislation of the Russian Federation, state standards and other regulatory documents, including international and national standards of other countries.

The peculiarity of the ecological certification's legal regulation is that in the latest environmental legislation, requirements for it are provided in a number of Russian and international acts that establish international standards and principles and which form the basis for the development of the entire ecological certification system. The special normative act on certification is the Federal Law dated on $27^{\text {th }}$ of December 2002 N184-FL "On Technical regulation".

The ecological certification system in Russia is based on the following basic principles: - establishment of domestic procedural rules and management for ecological certification that do not contradict the Fede ral Law "On Technical Regula tion";

- segregation of functions between va rious bodies of the ecological certification system;

- interaction of system with international and national certification bodies;

- distribution of responsibilities between participa nts of certification;

- coordination of the fiscal system and the pricing system with a n ecological certificate and the Environmental Compliance License.

In Russian Federation the ecological certification can be mandatory or voluntary. Mandatory certification is carried out by the certification body accredited in the manner established by the Government of Russian Federation on the basis of agreement with the applicant. Fig. 3. shows objects that are subject to mandatory certification in accordance with the legislation of the Russian Federa tion:

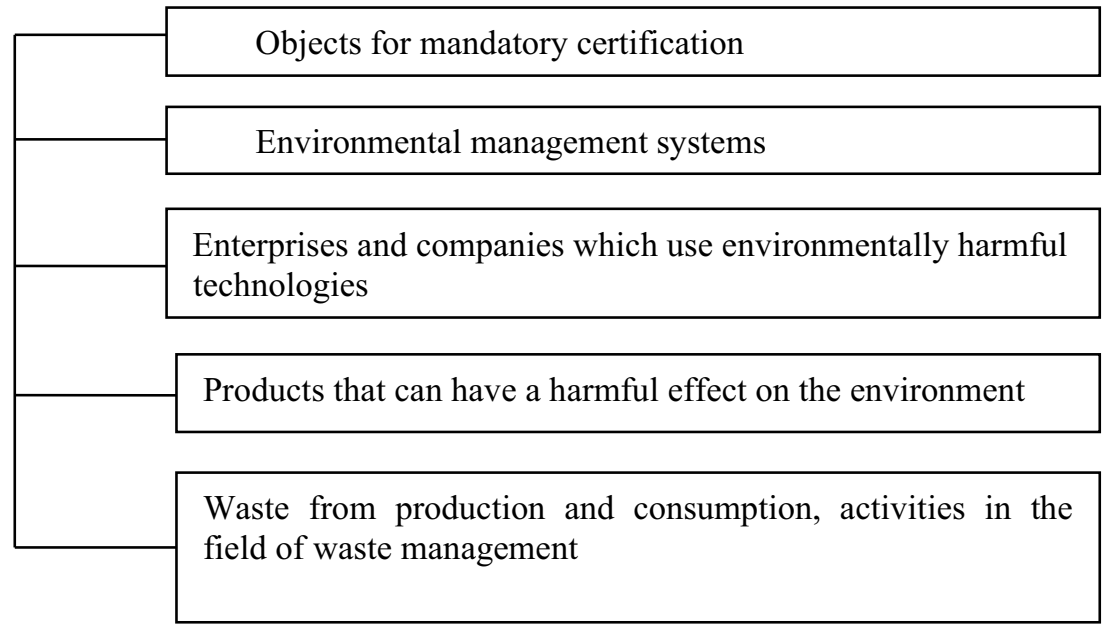

Fig. 3. Objects of mandatory certification in the Russian Federation 
When conducting mandatory certification there should be performed the researches (testing) and measurements of products under certification. This work must be carried out by the accredited testing laboratories (centers) under the terms of contracts with certification officials [8]. The certification bodies are not entitled to provide accredited testing labora tories (centers) with the information about the applicant.

The voluntary certification is carried out at the initiative of an applicant on the terms of agreement between the applicant and the certification body. It may aim to establish compliance with national standards, company standards, voluntary certification systems and contractual terms.

The objects for voluntary compliance statement are products, processes of production, operations, storage, transportation, sale and disposal, works and services, and other objects in relation to which requirements are established by standards, voluntary certification systems and contracts.

According to the unified Russian register of authorized voluntary certification systems there are about 640 companies what study environmental standards at enterprises. Totally in Russia (not only in the environmental sphere) there are more than 15 thousand certifying organizations and 85 thousand testing laboratories. At the same time the country still does not have a single center for ecological accreditation and, accordingly, a single regulation for this procedure.

\section{Results and Discussion}

Thus, we can distinguish two main approaches to understanding of ecological certification: as a measure of state regulation in the field of environment protection, and as an activity with specific features.

The area of ecologica 1 certification includes 6 groups of objects presented in Table 1:

Table 1. Types of ecological certification objects

\begin{tabular}{|c|c|}
\hline Objects & Types of certification objects \\
\hline Goods & environmental requirements are contained in the state standards \\
\hline $\begin{array}{l}\text { Technological } \\
\text { processes }\end{array}$ & $\begin{array}{l}\text { - aimed a the extraction and procurement of natural resources; } \\
\text { - related to the transportation of natural resources, products a nd wa ste; } \\
\text { - related to the storage of natural resources, products a nd waste; } \\
\text { - aimed at extracting (generation of) substances from natural resources; } \\
\text { - related to mechanical engineering, instrument making; } \\
\text { - aimed at reducing the harmful impacts of the main production on the environment. }\end{array}$ \\
\hline $\begin{array}{l}\text { Production } \\
\text { and } \\
\text { consumption } \\
\text { waste }\end{array}$ & $\begin{array}{l}\text { - arising from the extraction and procurement of natural resources; } \\
\text { - arising from the process of transportation of natural resources and products; } \\
\text { - arising in the process of storing natural resources and products; } \\
\text { - arising due to the main technological process during exploitation of natural } \\
\text { resources and products made of them; } \\
\text { - arising in the environmental technological process aimed at reducing the negative } \\
\text { impacts of the main production on the environment }\end{array}$ \\
\hline $\begin{array}{l}\text { Natural } \\
\text { resources }\end{array}$ & $\begin{array}{l}\text { - such a s land resources; } \\
\text { - such water resources; } \\
\text { - such as resources of vegetal and animal world; } \\
\text { - such as subsoil resources and minerals }\end{array}$ \\
\hline $\begin{array}{l}\text { Environmental } \\
\text { objects }\end{array}$ & $\begin{array}{l}\text { - such as protected natural objects intended for the preservation and reproduction of } \\
\text { ecosystems and certain types of natural resources, flora; fauna and landscapes; } \\
\text { - such as natural objects intended for domestic use. }\end{array}$ \\
\hline $\begin{array}{l}\text { Environmental } \\
\text { services }\end{array}$ & $\begin{array}{l}\text { - for production, installation, maintenance of environmental protection equipment, } \\
\text { repair of supervisory instruments for environmental protection; } \\
\text { - for recultivation, restoration, hygienization; }\end{array}$ \\
\hline
\end{tabular}




\begin{tabular}{|l|l}
\hline & $\begin{array}{l}\text { - for ecological education, personnel development, advanced training, } \\
\text { environmental audit report }\end{array}$ \\
\hline
\end{tabular}

The presence of an ecological certificate or eco-label is a determining factor in competitiveness for most products. In our days eco-labeling programs have found wide spread use around the world. At the same time, there is no generally accepted classification. In this article the author relies on the classification of ecological labels in accordance with ISO standard series 14000 .

International standards ISO 14021, 14024 and 14025 and their Russian versions establish requirements for voluntary eco-labeling programs of three main types - depending on the criteria for assessing compliance and the degree of independent (third) party's involvement in the environmental labeling process:

1. Type I: eco-labeling. It is a voluntary multi-criteria third-party's certification program, as a result of which a license is issued to use ecological la bels on products that indicate the overall environmental preference of products within a certain group of homogeneous products based on a full life cycle assessment (Life cycle assessment, LCA, GOST R ISO 14024-2000 "Labels and Environmental Declarations Eco-labeling of Type I Principles and Proce dures").

The program's credibility is determined primarily by the credibility of the operating organization, the openness of information about the evaluation criteria and their transparency.

Most of the type I eco-labeling programs are affiliated with the Global Eco-labeling Network (GEN). This association was created in 1994. Its main goal is to improve the e ffectiveness of the eological labels promotion at the intergovernmental level. It currently unites 27 programs.

On the territory of Russian Federation the consumers can find the following signs of international type I ecological labeling programs: "Blue Angel" (Germany), "European Flower" (European Union), "Northern Swan" (Scandinavian countries), "EcoLogo" (Canada), "Green Seal" (United States of America), "Eco-sign" (Japan) and "Leaf of Life" (Russia).

2. Type II: ecological self-declaration. The ecological declaration of manufacturer, importer, distributor, seller or any other party that may benefit from such a decla ra tion, made without certification by an independent third party (GOST R ISO 14021-2000 "Labels and Environmental Declarations se lf-declared ecological applications (Ecolabeling of type II)"). The standard describes the approaches to preparation of such applications, the use of certain terms and the requirements for confirmation of such statements by a third party.

3. Type III: ecological decla ra tion of products. Qualitative ecological da ta for any type of product according to predetermined categories of parameters is based on the standards of ISO series 14040, but without excluding additional ecological information provided a s part of type III eco-labeling declaration program (GOST R ISO 14025-2012 "Labels and Environmental Decla ra tions. Eco-la beling of type III. Principle s a nd Proce dure s") [9].

It should be noted that the developed countries are very apprehensive about the Russian certification bodies, since there is no confidence in the conformity verification procedure itself. Currently in Russia there is only one internationally recognized system of voluntary ecological certification type I, which meets the requirements of ISO standard 14024 - "Leaf of Life ". It was developed in 2001 by the non-commercial partnership NP "Ecological Union".

The international community recognized the Russian system of voluntary ecological certification in 2007, accepting NP "Ecological Union" as a member of GEN. In 2011, after an external audit, the program became a member of the International Program of Mutual 
Trust and was recognized by the world leading eco-la bels NP "E cological Union" carries out certification of non-food, food products and services.

In the present time in Russia there continue to be applied the departmental normative legal acts, regulatory and technical documents such as: state and sectoral standards (GOSTs, OSTs), building codes and regulations (SNiPs, SP, etc.), sanitary standards and rules (SANPiN, SanP). They duplicate and do not a lways correspond to the current legislation.

The results of the Russian legislation's analysis indicate that at the moment there is no definition of the concept "ecological certification" in any regulatory legal act. According to the Federal Law "On technical regulation", the certification is a form of confirmation of the objects' conformity to the requirements of technical regulations, provisions, standards or terms of contracts carried out by a certification body. At the same time, the law gave certification a new status, different from the one in which it existed during the period of law on certification of goods and services. If earlier in the general system of conformity assessment the certification acted as one of the main tools through which the compliance of products with the established mandatory requirements was determined. Now certification being one of the forms of mandatory confirma tion of conformity does not occupy the most important place in this system. But also in this fundamental federal law in the field of certifica tion, the conce pt of ecological certification is not defined. Thus, there is a procedure, but the current legislation does not contain an exact interpretation of this concept.

Based on our analysis, we believe that the development of environmental certification requires compliance with the following principles:

a) observance of the human rights to a healthy environment;

b) ensuring favorable conditions for human life;

c) a scientifically grounded combination of environmental, economic and social interests of a person, society and the state for sustainable development and ensuring a favorable environment and environmental safety;

d) protection, reproduction and rational use of natural resources as necessary conditions for ensuring a favorable environment and ecological safety;

e) the priority of preserving natural ecological systems, natural landscapes and natural complexes.

In fact, we are talking about compliance with the principles of a green economy, since environmental certification should be considered as a mechanism for the transition of the current economic system to an environmentally oriented type of management.

\section{Conclusion}

Today in Russia the ecological certification as a type of ecological service is not yet used to the extent that it should be applied in the country. The state has rich natural resources and industrial potential to lead in the global green market. However, there is initial stage of the environmental friendly goods and service s' market formation.

The legislation of the Russian Federation establishes that standardization and certification are carried out in order to ensure and control the safety of goods, works and services for the environment, human life and health. At the same time, the standards are mandatory for compliance without exception, and the certificates of conformity should be mandatory only for ce rtain types of products.

The example of state standard is GOST R 12.1.052-97 "Material Safety Data Sheet", the requirements of which are mandatory. However there are a lot of examples when new substances (materials) are introduced into the economic circulation and into the biological cycle when they don't have such a passport. Sometimes they are include various technical 
conditions, regulations. For example, about $20 \%$ of chemicals are used in oil production while they don't have approved maximum permissible concentrations or other standards for environmental impact.

In Russia there are problems of ignoring the requirements of mandatory standards and departmental fragmentation in the state control ove $r$ their implementation.

The problems of mandatory certification should be singled out separately. One of them is a disagreement be tween companies that assess the quality of products.

The second problem of mandatory eco-certification is the issue of a single list of products subject to mandatory certifica tion, which was approved by the Decree of Russian Federation Government on $1^{\text {st }}$ of December 2009 N982. Initially the list contained more than 400 names of objects subject to mandatory certification. But the decade later the list has undergone a number of changes. At present in the current edition the list of provisions has been reduced by more than two times. Therefore, it can be concluded that the level of quality control for manufactured and imported goods has decreased and this fact negatively affects the environmental situation as a whole.

The study has shown that environmental certification plays an important role in ensuring food security. The increasing requirements of consumers lead to the need of the innovation development of the agricultural sector, new technologies implementation based on environmental friendly approaches. This approach is aimed at achieving sustainability of agriculture, compliance with the principles of resource conservation. It is especially important to achieve the stability of the agricultural sector in order to ensure the country's independence from external factors, to achieve economic and food security. The consequences of pandemic had led to a disruption in logistics, trade between countries that could serve as a proof of the need to develop sustainable agriculture system. However, the most important thing is to care for human health, safety of consumed products. Therefore, environmental certification is an important element in ensuring sustainable agricultural development in the context of a green economy and environmental management in Russia.

We suggest using environmental certification as a tool for the following types of activities:

- application of ecological and economic approaches in the management of the territory. The implementation of modern strategies and programs for the development of cities or townships includes taking into account environmental requirements for the formation of a high-quality living environment, human health and their environmental safety;

- environmental audit. In the process of environmental audit, it is necessary to assess the goods and services produced for compliance with environmental standards and norms;

- public private partnership. The implementation of the PPP mechanism in the implementation of investment projects requires compliance with environmental legislation and an assessment of the investment project in relation to environmental requirements, the ability to comply with the principles of sustainable development.

We also believe that the problem of environmental certification can be expanded by improving methods and approaches to its implementation, as well as areas where it can be applied. For example, Russia can introduce energy certification of goods and services in accordance with the principles of a green economy. Given the growing trend towards the development of the climate agenda, certification for climate requirements could also be introduced to reduce climate risks. We are talking about the certification of goods, services and industries that reduce the carbon footprint and minimize the impact on the environment in terms of climate. Research in this area is promising and insufficiently studied at the present time.

The paper is funded by RFBR, project № 19-010-00194 A 


\section{References}

1. R. Laurett, A. Paço, E. W. Mainardes, An Exploratory Study, Sustainable Production and Consumption, 27, 298-311 (2021)

2. X. Font, Tourism Management, 23, 3, 197-205 (2002)

3. M.A.O. Torres, Z. Kallas, S.I.O. Herrera, Land Use Policy, 99, 105031, (2020)

4. C. Griesche, A.J. Baeumner, Trends in Analytical Chemistry (TrAC), 128, 115906 (2020)

5. N.R. Brown, R.F. Noss, D.D. Diamond, M.N. Myers, Journal of Forestry, 99(8), 18 25 (2001)

6. V. Gassiy, V. Stoikov, E3S Web of Conferences, 207, 02009 (2020)

7. A. Blackman, M.A. Naranjo, Does Eco-Certification Have Environmental Benefits? (Resources for the future, Washington, 2010)

8. D.B. Paz, K. Henderson, M. Loreau, Ecological Modelling, 437, 109312 (2020) 